\title{
Model research of the energy efficiency of a cogeneration backpressure steam turbine installation
}

\author{
Ivan Genovski ${ }^{1}$ and Kaloyan Hristov ${ }^{1, *}$ \\ ${ }^{1}$ Technical University of Sofia, Department of Thermal Power Engineering and Nuclear Power \\ Engineering, 1000, 8 Kl. Ohridski Blvd, Sofia, Bulgaria
}

\begin{abstract}
In the contemporary district heating systems (DHS) heat energy for the customers is generated by cogeneration method, which leads to the saving of primary energy resources compared to the separate production method. The most widespread technology for combined production is based on steam turbine installations with adjustable steam extraction and backpressure steam turbine. In these technologies district heating water is heated to the required temperature either in district heaters in case of steam turbine with adjustable steam extractions or in boiler-condenser in case of backpressure steam turbine installations. The temperature of the district heat water at the inlet of the CHP installation depends on the mode of operation of the DHS. The heat load, distributed to consumers, is regulated at the heat source (CHP installation) by temperature and flow rate of the district heating water, mainly following the change in climatic factors. Current study presents the development of a simulation model of existing CHP backpressure steam turbine. The object studied is a backpressure steam turbine type SST-300 CE2L/V36S. Presented are results from the validation of the simulated model with data from the design documentation. The model has been used to study the energy efficiency of a steam turbine installation based on multivariate simulation calculations. The results obtained relate the energy efficiency indicators of CHP backpressure steam turbine with the factors that characterize the mode of operation of the district heating system.
\end{abstract}

\section{Combined production of heat and electricity in district heating systems}

In the thermal power plants combined heat and power production is realized, which allows more efficient use of the primary energy resources. The heat generated in the plant ( $\left.\mathrm{Q}_{\mathrm{DHS}}\right)$ is supplied to domestic and industrial consumers through the district heating system. Cogeneration production of electricity and heat energy are most often realized through steam turbines with adjustable steam extraction or backpressure.

\footnotetext{
*Corresponding author: kokhris@gmail.com
} 
Steam turbines with adjustable steam extraction achieve their full electric power regardless of their heat load. The produced electricity is combined when generated by the steam extracted from the turbine to supply the heat load of the consumers, and condensed when generated by the steam flow entering the condenser.

Backpressure steam turbines produce electricity only by a combined method, and the power follows the variation of the heat load distributed to the consumers. Since the specific fuel consumption for the production of electricity employing the condensation method is higher than this when using a combined method $[1,2]$ these installations are more efficient than those with adjustable steam extraction.

In 2019 a new backpressure steam turbine type SST-300 CE2L/V36S was commissioned in the biggest district heating power plant in Bulgaria - TPP "Sofia Iztok", which replaced the existing installation PT-30-90/10 with adjustable steam extraction.

The SST-300 CE2L/V36S steam turbine installation includes a steam turbine operating at high speed $(5900 \mathrm{rpm})$. The rotational force of the steam turbine is transmitted to the electric generator by a gearbox (GB), which reduces the speed to $1500 \mathrm{rpm}$. The turbine is single-cylinder and contains a high-pressure part- (HP) and a low-pressure part (LP). The auxiliary equipment of the installation includes: low-pressure feedwater heater (LPFWH), deaerator (DA) and high-pressure feedwater heater (HPFWH).

The steam turbine has two steam extractions: a non-adjustable and an adjustable one. The district water for the heat supply system is heated in the boiler-condenser (BC) using steam, which enters after the final stage of the turbine.

Fig.1 presents the technological scheme of the studied cogeneration installation.

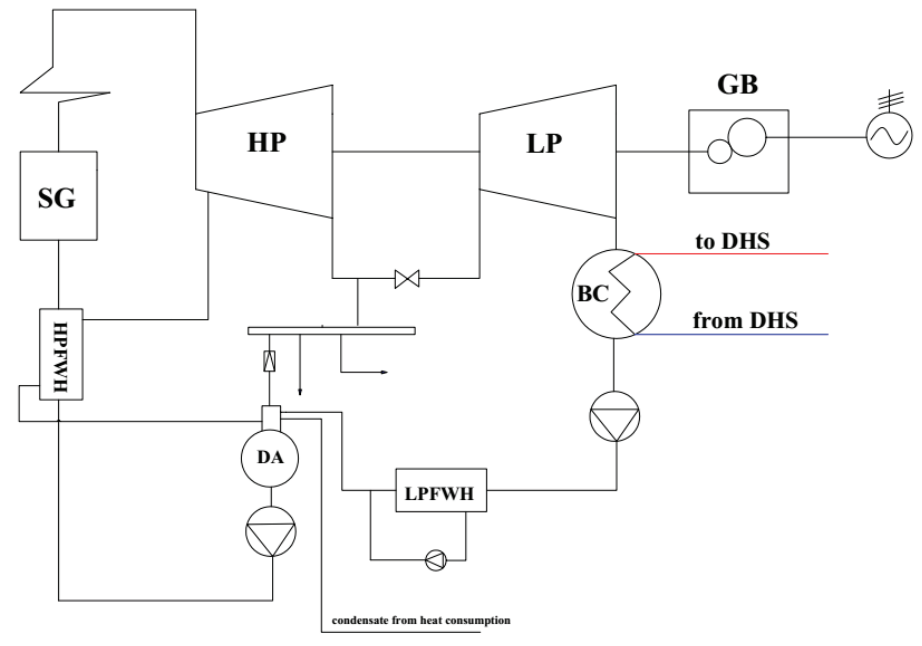

Fig. 1. Technological scheme of backpressure steam turbine type SST-300 CE2L/V36S.

The steam pressure in the adjustable steam extraction varies from 0.78 to $1.27 \mathrm{MPa}$, and the maximum steam flow through it is $14.01 \mathrm{~kg} / \mathrm{s}$. The steam of the high-pressure feed water heater is supplied by the non-adjustable steam extraction of the turbine. The deaerator and the low-pressure heater are supplied with steam from the adjustable steam extraction after pressure reducing. The maximum heat output of the condenser is $90 \mathrm{MW}$, and the maximum district water through it $-650 \mathrm{~kg} / \mathrm{s}$. The steam pressure in the boiler-condenser varies in the range from $40 \mathrm{kPa}$ to $250 \mathrm{kPa}$, which provides heating of the mains water from 70 to $120^{\circ}$. Part of the steam from the adjustable extraction is used for internal heat consumption needs, and in case of excess is directed to the district heaters servicing the plant. 


\section{Energy efficiency indicators}

The efficiency of cogeneration plants is assessed with energy efficiency indicators, which in Bulgaria are regulated by EU Directive 2012/27 [3]. According to this directive, the efficiency of cogeneration plants is evaluated by two indicators - total CHP system efficiency $\left(\eta_{\text {total. chp }}, \%\right)$ and fuel saving $(\Delta \mathrm{F}, \%)[4]$.

Total CHP system efficiency is the ratio between the sum of the electricity and heat produced by the cogeneration unit to the heat equivalent of the fuel used for their production:

$$
\eta_{\text {total. chp }}=\frac{P+Q_{\text {chp }}}{F_{\text {chp }}} \cdot 100
$$

where:

$\mathrm{P}$ - electrical energy, produced by the CHP installation, $\mathrm{kWh}$;

$\mathrm{Q}_{\mathrm{chp}}$ - heat energy produced by the CHP installation, $\mathrm{kWh}$;

$\mathrm{F}_{\text {chp }}$ - total fuel input in CHP installation, kWh.

The total system efficiency does not provide complete information of the completeness of the thermal processes in cogeneration plants. High values of the total energy efficiency of plants do not always lead to fuel savings in production [4].

The most complete assessment of the energy efficiency of cogeneration plants is obtained after determining the fuel saving when comparing the combined method with the separate one when producing the same amount of electricity and heat $[3,4]$.

The fuel saving is calculated using the following equation [4]:

$$
\Delta \mathrm{F}=\left(1-\frac{\mathrm{F}_{\text {chp }}}{\frac{\mathrm{P}}{\eta_{\mathrm{el}}}+\frac{\mathrm{Q}_{\text {chp }}}{\eta_{\mathrm{Q}}}}\right) .100
$$

where:

$\eta_{\mathrm{el}}$ - efficiency of electrical power generation of the replacement condenser block from the separated production, \%;

$\eta_{\mathrm{Q}}-$ efficiency of heat energy production from the hot-water boiler from the separated production, $\%$.

The efficiency reference values for separate production, according to EU Directive $2012 / 27$, depend on the type of fuel burned and the year of commissioning the cogeneration unit.

The efficiency of the steam turbine installation can be assessed with the specific fuel consumption for the production of electricity $\left(b_{\text {el.chp }}, g / k W h\right)$ and heat energy $\left(b_{\text {chp } Q}\right.$, $\mathrm{g} / \mathrm{kWh})[5,6]$. In the physical method of fuel distribution between the two products, adopted in Bulgaria, the specific fuel consumption for heat production does not depend on the parameters of the allocated heat load. In the fuel with a lower calorific value of 29330 $\mathrm{kJ} / \mathrm{kg}$, the specific fuel consumption for heat production is determined by the equation:

$$
\mathrm{b}_{\text {chp Q }}=\frac{0.123}{\eta_{\mathrm{Q}}^{\text {chp }}}
$$


where: $\eta_{\mathrm{Q}}^{\text {chp }}$ is the efficiency of heat production in the cogeneration unit, $\%$.

The value of efficiency of heat production in the cogeneration unit ( $\eta_{\mathrm{Q}}^{\text {chp }}$ ) depends on the efficiency of the steam generator, which produces steam for the cogeneration unit, the steam pipe system and the district heaters.

The specific fuel consumption for electricity production $\left(b_{\text {el.chp }}\right)$ depends on the efficiency of electricity production of the cogeneration unit $\left(\eta_{\mathrm{el}}^{\mathrm{chp}}\right)$, whose value is influenced by the size and parameters of the heat load supplied to consumers. For the determined the specific fuel consumption for electricity production can using the following equation:

$$
\mathrm{b}_{\mathrm{el} . \mathrm{chp}}=\frac{0.123}{\eta_{\mathrm{el}}^{\mathrm{chp}}}
$$

In order to estimate the efficiency of electricity production of the cogeneration unit it is necessary to compile equations for energy and material balance of the cogeneration unit.

In the present study, the developed simulation model is used to evaluate the energy efficiency of the cogeneration unit.

\section{Simulation model}

The software product for simulation modeling GateCycle is a convenient tool for modeling the thermal mode of operation of the steam turbine installation. It allows studying different variable regimes of operation of steam turbine plants for cogeneration $[7,8,9]$.

The calculations performed with it are based on the law of conservation and conversion of energy. The software allows a detailed examination of the behavior of the equipment that is an integral part of the steam turbine installation. The program provides information on: pressure, temperature and flow of working fluids (air, water vapor, fuel) at each point of the technological scheme [10].

The scheme of the steam turbine installation for cogeneration SST-300 CE2L/V36S in the environment for simulation modeling is shown in Fig.2.

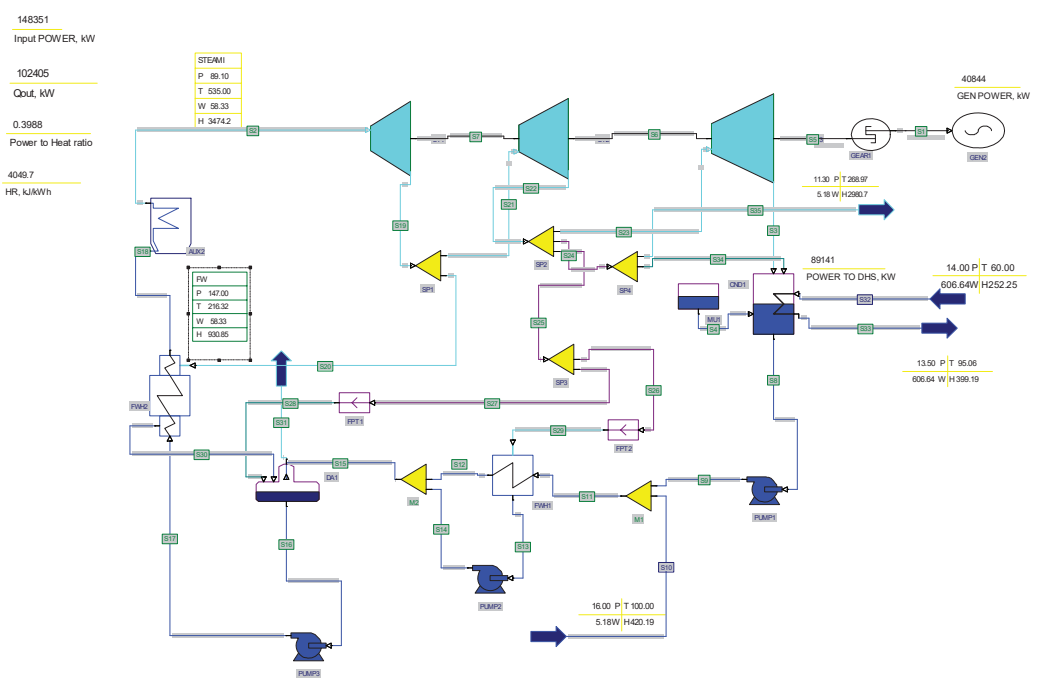

Fig. 2. Simulation scheme on steam turbine type SST-300 CE2L/V36S. 
In the simulation software, the steam turbine is presented as a three-cylinder one using the tools available in the program. This is necessary in order to model the operation of the adjustable and non-adjustable steam extractions of the turbine. The boundary of the first body of the turbine in the simulation environment is from its inlet to the non-adjustable steam extraction, which supplies HPFWH. The steam parameters at the outlet of the first cylinder are the initial parameters for the second cylinder. The first two cylinders are the high-pressure (HP) part of the steam turbine. The SPLITER element with one input and three outputs is used to model the adjustable steam extraction. The input for this tool is the output of the second cylinder. The first output is connected to the third cylinder in the modeling environment, which corresponds to the low-pressure (LP) part of the steam turbine. The steam flow through it is regulated depending on the heat load of the consumers. The adjustable steam extraction is presented with the second output, where by means of the auxiliary menus of the software a possibility for control of the steam consumption is set. The third output supplies steam to the plant's deaerator and LPFWH. The value for the internal relative efficiency of the steam turbine is set to $84.9 \%$.

When modeling the boiler-condenser, both the permissible range of change of the steam pressure and a limit of the flow of mains water through it is set (maximum value $650 \mathrm{~kg} / \mathrm{s}$ ). The model introduces the main design features of the boiler-condenser (number of passes, heating surface, inner and outer diameter of the pipes, etc.).

The initial parameters of the steam are in accordance with the technical documentation of the steam turbine installation (initial pressure $\mathrm{p}_{0}=8.91 \mathrm{MPa}$ and initial temperature $\left.\mathrm{t}_{0}=535^{\circ} \mathrm{C}\right)$.

To assess the accuracy of the developed model, calculations were performed for two regimes of operation of the installation and the results of the calculations were compared to the respective values of its design documentation. The compared parameters are: fuel consumption, temperature and pressure of inlet steam, steam pressure and temperature in the adjustable steam extraction, steam pressure in the boiler-condenser, feedwater temperature, electricity generated by the steam turbine installation and heat produced in the boiler-condenser.

The results of the model validation are presented in Table 1 and Table 2.

In the first regime (Table 1) the steam consumption at the turbine inlet is at maximum and the cogeneration unit realizes its maximum electrical power.

Table 1. Results of model validation for the first regime

\begin{tabular}{|c|c|c|c|c|}
\hline Parameters & Unit & Project & Model & Deviation, \% \\
\hline Inlet steam flow & $\mathrm{kg} / \mathrm{s}$ & 58.33 & 58.33 & - \\
\hline Inlet steam temperature & ${ }^{\circ} \mathrm{C}$ & 535 & 535 & - \\
\hline Inlet steam pressure & $\mathrm{MPa}$ & 8.9100 & 8.9100 & - \\
\hline Adjustable steam extraction flow & $\mathrm{kg} / \mathrm{s}$ & 14.01 & 14.01 & - \\
\hline $\begin{array}{c}\text { Pressure steam in adjustable steam } \\
\text { extraction flow }\end{array}$ & $\mathrm{MPa}$ & 1.1000 & 1.1000 & - \\
\hline $\begin{array}{c}\text { Steam pressure in boiler- condenser } \\
\text { Feedwater temperature }\end{array}$ & $\mathrm{MPa}$ & 0.1052 & 0.1087 & 3.33 \\
\hline Electrical energy & $\mathrm{M} C$ & 216.80 & 216.32 & -0.22 \\
\hline
\end{tabular}


Heat energy on boiler-condenser

MWh

89.81

89.14

$-0.75$

In the second regime (Table 2) the operation of the installation at minimum inlet steam for cogeneration is studied.

Table 2. Results of model validation for the second regime

\begin{tabular}{|c|c|c|c|c|}
\hline Parameters & Unit & Project & Model & Deviation, $\%$ \\
\hline Inlet steam flow & $\mathrm{kg} / \mathrm{s}$ & 25 & 25 & - \\
\hline Inlet steam temperature & ${ }^{\circ} \mathrm{C}$ & 535 & 535 & - \\
\hline Inlet steam pressure & $\mathrm{MPa}$ & 8.9100 & 8.9100 & - \\
\hline Adjustable steam extraction flow & $\mathrm{kg} / \mathrm{s}$ & 4.93 & 4.59 & -6.09 \\
\hline $\begin{array}{c}\text { Pressure steam in adjustable steam } \\
\text { extraction flow }\end{array}$ & $\mathrm{MPa}$ & 1.1000 & 1.1000 & - \\
\hline Steam pressure in boiler- condenser & $\mathrm{MPa}$ & 0.0456 & 0.0455 & -0.22 \\
\hline Feedwater temperature & ${ }^{\circ} \mathrm{C}$ & 195.5 & 194.28 & -0.61 \\
\hline Electrical energy & MWh & 16.574 & 16.808 & 1.41 \\
\hline Heat energy on boiler-condenser & MWh & 45.880 & 47.714 & 4.00 \\
\hline
\end{tabular}

The obtained results show that the model "recreates" the data from the project documentation with acceptable accuracy. The largest deviation is observed in regime 2, when the steam turbine installation operates at minimum steam load. In this case, the result for steam consumption during the regulated steam extraction from the model study deviates from the one indicated in the technical documentation by $6.09 \%$. The deviation of the values required for the technical and economic calculations (produced electricity, heat energy realized by the boiler-condenser and the temperature of the feed water) does not exceed $4 \%$. The obtained results give grounds to use the model to study the operating modes of the cogeneration plant.

\section{Research of the energy efficiency of a cogeneration steam turbine type SST-300 CE2L/V36S}

The heat load is delivered to the consumers with a certain flow rate $(\mathrm{G}, \mathrm{kg} / \mathrm{s})$ and with a certain temperature of the water to district heating system $\left(\tau_{1},{ }^{\circ} \mathrm{C}\right)$. The temperature of the water from district heating system $\left(\tau_{2},{ }^{\circ} \mathrm{C}\right)$ is the resultant value of heat consumption in the heat supply system and its value depends on the regime of operation of the district heating system.

The change of each of the parameters $\left(G, \tau_{1}, \tau_{2}\right)$ leads to a change of the pressure in the boiler-condenser, which affects the thermal efficiency of the steam turbine installation. The heavier load of the boiler-condenser leads to higher inlet steam flow and the CHP installation is more efficient.

The main parameter characterizing the district heating regime of the plant is the production of electricity based on heat consumption (power to heat ratio), which is the ratio of the electricity produced by the combined method $(\mathrm{P})$ to the heat released to the heat supply system $\left(\mathrm{Q}_{\text {chp }}\right)$ from the steam turbine $[5,11]$. At a given consumer heat load this 
indicator depends on the regime of operation of the turbine, and the main regime factor is the pressure in the boiler-condenser.

The saturation steam temperature in the boiler-condenser, at which the phase transition is performed, can be determined by the temperature of the incoming district heating water $\left(\tau_{2}\right)$, the magnitude of its heating $(\Delta \tau)$ and the temperature difference of the flows in the heat exchanger $(\delta \mathrm{t})$. At an already determined steam condensing temperature $\left(t_{s}\right)$, the pressure $\left(\mathrm{p}_{\mathrm{s}}\right)$ in the boiler-condenser can also be determined. The saturation temperature of the steam in the boiler-condenser is determined by the following equation:

$$
\mathrm{t}_{\mathrm{s}}=\tau_{2}+\Delta \tau+\delta \mathrm{t}
$$

When operating the steam turbine installation according to the district heating schedule, the electric power developed by the turbine largely depends on the temperature of district heating water, with which it enters the boiler installation. The higher temperature of district heating water leads to an increase in pressure in the boiler-condenser, which unloads the turbine, both in terms of heat output and electricity production.

In the present publication based on the developed simulation model the influence of the temperature of the water from district heating $\left(\tau_{2}\right)$ and the magnitude of its heating in the boiler-condenser is investigated.

The input data for the calculations are:

- Maximum load of the boiler-condenser - 90 MW. Through the adjustable steam extraction no heat is released to external users;

- Maximum flow on district heating water through the boiler-condenser is $650 \mathrm{~kg} / \mathrm{s}$;

- Change in temperature of the mains water, which enters the boiler-condenser, from 50 to $60^{\circ}$;

- Heating of the district water in the boiler-condenser ( ) from 44 to $50^{\circ}$;

- Change of steam pressure in the boiler-condenser from 0.040 to $0.250 \mathrm{MPa}$.

Multivariable calculations were performed employing this model. Results were obtained for the variation of the following parameters:

- Electrical power on cogeneration steam turbine (P, MW);

- Specific fuel consumption for electricity production $\left(\mathrm{b}_{\mathrm{el} . c h p}, \mathrm{~g} / \mathrm{kWh}\right)$;

- Total CHP system efficiency of the cogeneration steam turbine ( $\left.\eta_{\text {total. chp }}, \%\right)$;

- Fuel saving of the cogeneration steam turbine $(\Delta \mathrm{F}, \%)$.

The results of the simulation calculation are presented graphically depending on the initial temperature of the incoming district heating water (2), with which it enters the cogeneration power plant.

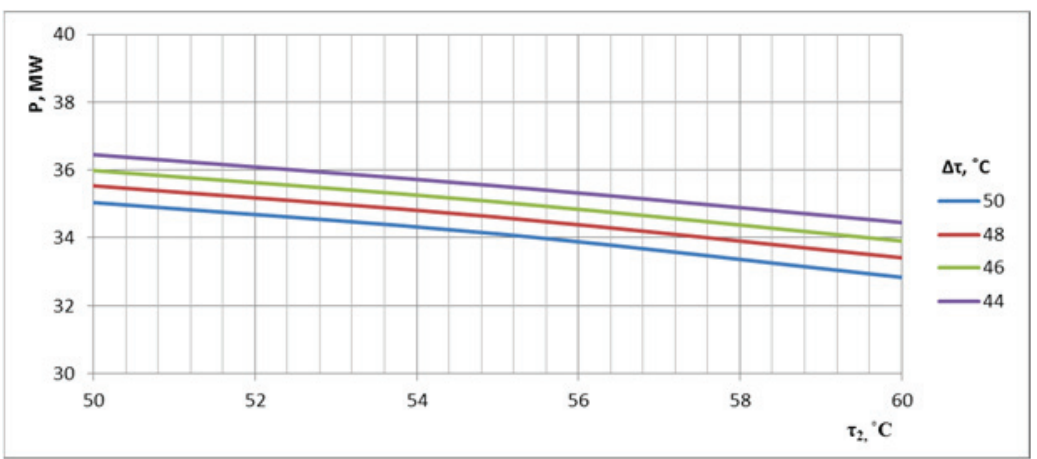

Fig. 3. The electric power of the cogeneration unit depending on the temperature of the incoming district heating water and the magnitude of its heating in the boiler-condenser. 
Figure 3 shows the change in the electric power $(\mathrm{P})$ of the cogeneration unit. It can be seen that as the temperature of the incoming district heating water (2) decreases, the electrical power of the installation grows due to the increase of the processed enthalpy drop from the turbine. The same effect is observed by the decrease of water heating ( ).

In Fig. 4 are presented the results of the simulation study of the change of the specific fuel consumption for production of electricity from the installation for cogeneration as a function of the temperature of the district heating water ( 2 ). The specific fuel consumption is determined at $90 \%$ efficiency of the steam generator and efficiency of the steam pipelines $96 \%$. As the temperature of the mains water entering the boiler-condenser decreases, the specific fuel consumption for electricity production also decreases, which is explained by the increased production of combined electricity.

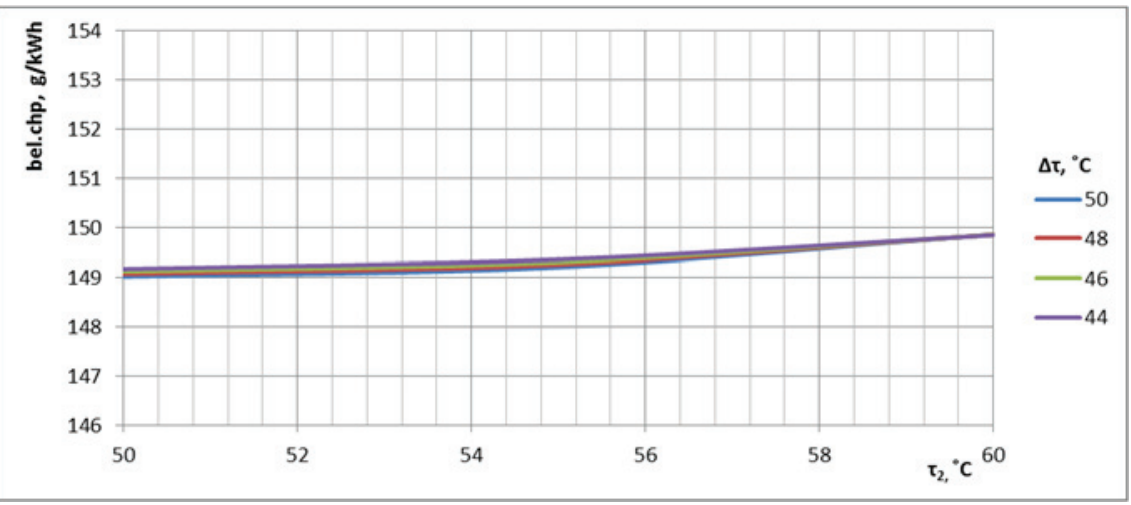

Fig. 4. Specific fuel consumption for electricity production of the cogeneration unit depending on the temperature of the incoming district heating water and the magnitude of its heating in the boilercondenser.

The specific fuel consumption for heat production from the installation is not affected by the parameters of the released heat load and is equal to $141 \mathrm{~g} / \mathrm{kWh}$. This is a feature due to the physical method used in Bulgaria for distribution of fuel between the produced heat and electricity in the cogeneration plant.

The change of the total CHP system efficiency of the installation depending on the temperature of the incoming district heating water is presented in Fig.5. It can be seen that the total CHP system efficiency of the installation remains unchanged when the temperature and the magnitude of heating of the incoming water district heating in the boiler-condenser of the installation change.

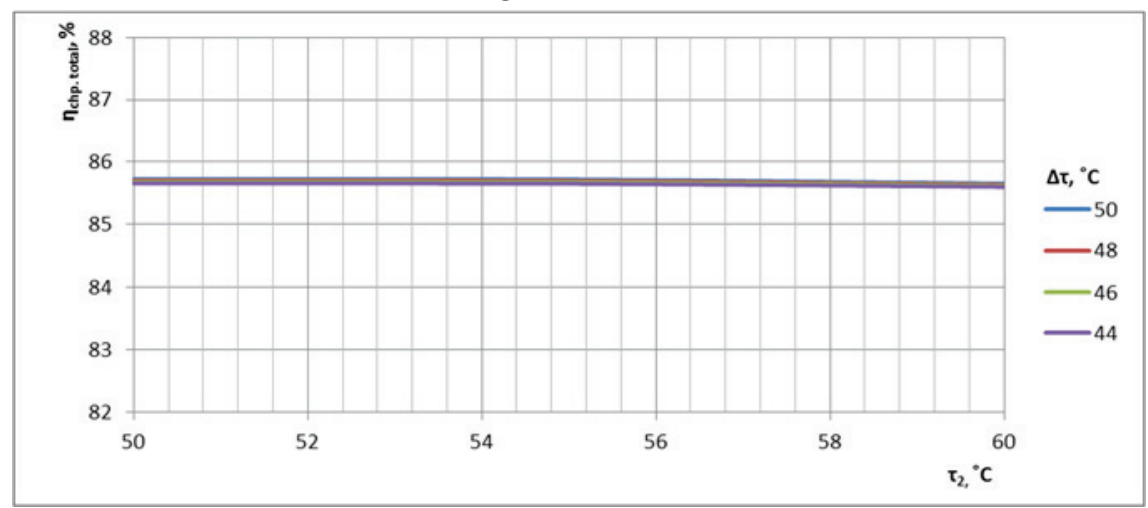

Fig. 5. The total CHP system efficiency of the cogeneration unit depending on the temperature of the incoming district heating water and the magnitude of its heating in the boiler-condenser. 
Fig. 6 shows the change in fuel saving ( F) according to the EU Directive 2012/27. When determining the fuel saving, reference values for the efficiency were used for electricity production $-52.5 \%$ and for heat production $-90 \%$, which correspond to the natural gas used in the installation, without making a temperature correction according to the ambient temperature and without taking into account the consumption of electricity by the cogeneration unit.

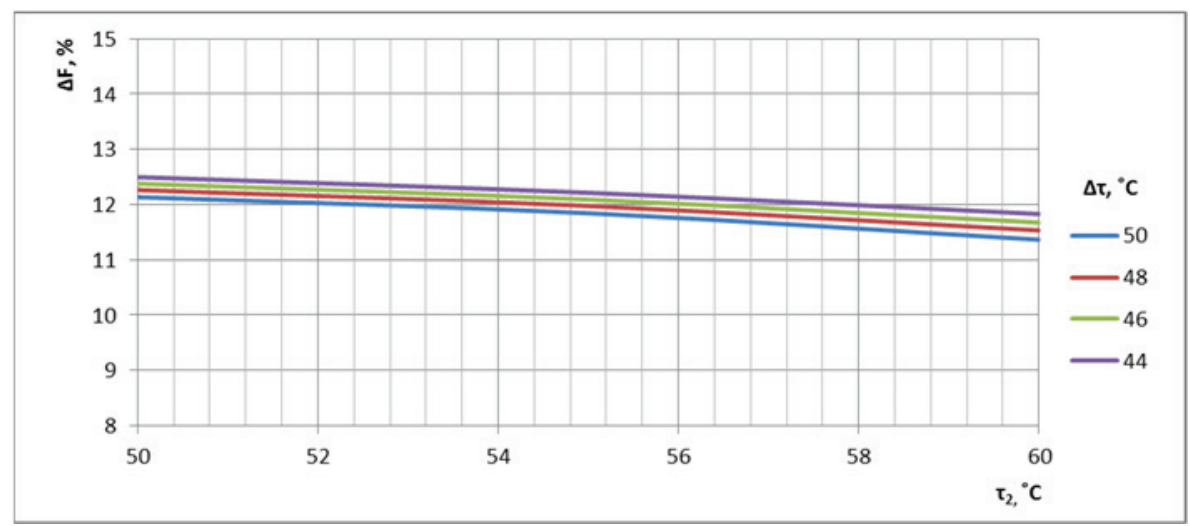

Fig. 6. The fuel saving of the cogeneration unit depending on the temperature of the incoming district heating water and the magnitude of its heating in the boiler-condenser.

The obtained results show that the fuel savings as a result of cogeneration production are more than $10 \%$ in the whole range of changes the temperature of the incoming district heating water and the magnitude of its heating, therefore according to EU Directive 2012/27 the produced electricity is "High-efficiency". Fuel savings increase with combined electricity production.

\section{Conclusion}

This report develops a simulation model of a backpressure steam turbine installation for cogeneration type SST-300 CE2L/V36S. The model was validated by comparing the results of two regimes of operation with the values from the design documentation of the turbine.

Using the simulation model an analysis of the energy efficiency of the steam turbine installation at nominal heat load of the boiler-condenser (90 MW) depending on the change of the mains water temperature (from 50 to $60^{\circ}$ ) entering the boiler-condenser and the size of its heating (from 44 to $50{ }^{\circ} \mathrm{C}$ ) is performed.

The obtained results show that the energy efficiency indicators of the cogeneration unit are improved by decreasing the temperature of the water from district heating, which enters the boiler-condenser. The same pattern is observed when reducing its heating. Since the temperature of the incoming district heating water is a function of the consumed heat in the heating system, it cannot be regulated. Thus, to improvement of the energy efficiency of the backpressure steam turbine installation can be achieved by reducing the magnitude of heating of the incoming district heating water in the boiler-condenser (by increasing the flow rate through it).

\section{References}

1. T. Al-Shemmeri, R. Beith, "Thermodynamics, performance analysis and computational modelling of small and micro combined heat and power (CHP) systems", ed: Woodhead Publishing, 42-69, (2011). 
2. M. Chen, H. Lund, L. Rosendahl, T. Condra, "Energy efficiency analysis and impact evaluation of the application of thermoelectric power cycle to today's CHP systems". AE, 87, 1231-1238, (2010).

3. Directive 2012/27/EU.

4. Catalog of CHP Technologies, U.S. EPA, (2017).

5. C. Gochenour, "Regulation of heat and electricity produced in combined-heat-and-power plants", Washington, D.C.: World Bank Group, 1, (2003).

6. G. Cimdina, D. Blumberga, I. Veidenbergs, "Analysis of wood fuel CHP operational experience", Energy Procedia, 72, 263 - 269, (2015).

7. Genovski, K. Hristov, "Optimal heat load distribution between cogeneration steam turbine installations in combined heat and power (CHP) plant", JMTI, 1, 30-46, (2014).

8. T. Savola, I. Keppo, "Off-design simulation and mathematical modeling of small-scale CHP plants at part loads", Appl. Therm. Eng, 25, 1219-1232, (2005).

9. T. Totev, B. Ignatov, "Tehnico-economic and ecologic assessment of lignite-fired power unit", International Energy Forum 2019, 120-130, Varna, Bulgaria, (2019).

10. T. Totev, B. Ignatov, "Possible solutions for the reduction of carbon emissions during operation of lignite power unit", International Energy Forum 2019, 131-143, (2019).

11. U. Fahl, A. Dobbins, "Chapter 29 - District Heating in Europe: Opportunities for Energy Savings, Business, and Jobs”, Europe's Energy Transition: Insights for Policy Making, 249-259, (2017). 